\title{
Caspr and Caspr2 Are Required for Both Radial and Longitudinal Organization of Myelinated Axons
}

\author{
(D)Aaron Gordon, ${ }^{1 \star}$ Konstantin Adamsky, ${ }^{1 \star}$ Anya Vainshtein, ${ }^{1}$ Shahar Frechter, ${ }^{1}$ Jeffrey L. Dupree, ${ }^{2}$ Jack Rosenbluth, ${ }^{3}$ \\ and Elior Peles ${ }^{1}$ \\ ${ }^{1}$ Department of Molecular Cell Biology, Weizmann Institute of Science, Rehovot 76100, Israel, ${ }^{2}$ Department of Anatomy and Neurobiology, Virginia \\ Commonwealth University, Richmond, Virginia 23298, and ${ }^{3}$ Department of Neuroscience \& Physiology, New York University School of Medicine, New \\ York, New York 10016
}

In myelinated peripheral axons, Kv1 potassium channels are clustered at the juxtaparanodal region and at an internodal line located along the mesaxon and below the Schmidt-Lanterman incisures. This polarized distribution is controlled by Schwann cells and requires specific cell adhesion molecules (CAMs). The accumulation of Kvl channels at the juxtaparanodal region depends on the presence of Caspr2 at this site, as well as on the presence of Caspr at the adjacent paranodal junction. However, the localization of these channels along the mesaxonal internodal line still persists in the absence of each one of these CAMs. By generating mice lacking both Caspr and Caspr2 $\left(\right.$ caspr $^{-1-} /$ caspr $\left.^{-1-}\right)$, we now reveal compensatory functions of the two proteins in the organization of the axolemma. Although Kv1 channels are clustered along the inner mesaxon and in a circumferential ring below the incisures in the single mutants, in sciatic nerves of caspr $^{-1-} /$ caspr $2^{-1-}$ mice, these channels formed large aggregates that were dispersed along the axolemma, demonstrating that internodal localization of Kv1 channels requires either Caspr or Caspr2. Furthermore, deletion of both Caspr and Caspr2 also resulted in widening of the nodes of Ranvier, suggesting that Caspr2 (which is present at paranodes in the absence of Caspr) can partially compensate for the barrier function of Caspr at this site even without the formation of a distinct paranodal junction. Our results indicate that Caspr and Caspr2 are required for the organization of the axolemma both radially, manifested as the mesaxonal line, and longitudinally, demarcated by the nodal domains.

Key words: adhesion molecule; axon-glia interaction; Caspr; myelin; node of Ranvier; peripheral nerve

\section{Introduction}

Localized clustering of ion channels along myelinated axons is essential for the fast propagation of action potentials. The unique structure of the myelin sheath in the peripheral nervous system (PNS) confers both longitudinal and radial polarity to the underlying axolemma. Ion channel clusters are found in distinct domains including the longitudinally arranged node of Ranvier, paranodal junction (PNJ), and the juxtaparanodal region (JXP), as well as at the radially arranged mesaxonal line present throughout the internode and below the Schmidt-Lanterman incisures (SLIs; Poliak and Peles, 2003). The radial polarity reflects the clustering of kvl channels at specific sites around the axonal circumference. The localization of ion channels in specific mem-

Received Aug. 13, 2014; revised Sept. 14, 2014; accepted Sept. 24, 2014.

Author contributions: K.A. and E.P. designed research; A.G., K.A., A.V., S.F., and J.R. performed research; A.G., K.A., J.L.D., and J.R. analyzed data; E.P. wrote the paper.

This work was supported by the National Institutes of Health (Grant NS50220 to E.P. and Grant NS037475 to J.R.) the Israel Science Foundation, and the Dr. Miriam and Sheldon G. Adelson Medical Research Foundation. E.P. is the Incumbent of the Hanna Hertz Professorial Chair for Multiple Sclerosis and Neuroscience. We thank Matthew Rasband for antibodies and Peter Shrager for discussion.

The authors declare no competing financial interests.

${ }^{*}$ A.G. and K.A. contributed equally to this work.

Correspondence should be addressed to Dr. Elior Peles, Department of Molecular Cell Biology, Weizmann Institute of Science, Rehovot 76100, Israel; e-mail: peles@weizmann.ac.il.

DOI:10.1523/JNEUROSCI.3369-14.2014

Copyright $\odot 2014$ the authors $\quad 0270-6474 / 14 / 3414820-07 \$ 15.00 / 0$ brane domains depends on specific cell adhesion molecules (CAMs), as well as on the integrity of neighboring domains. For example, the localization of Kv1 channels at the JXP depends on the presence of both Caspr2 and Cntn2, which serves as a membrane scaffold. Deletion of either of these CAMs causes Kv1 channels to disappear from the JXP and to redistribute along the internode (Poliak et al., 2003; Traka et al., 2003). The localization of Kv1 channels at the JXP also depends on the correct formation of a membrane cytoskeletal barrier at the PNJ that flank the nodes of Ranvier. When the paranodal barrier is disrupted, as is the case in the absence of Caspr (Bhat et al., 2001; Sun et al., 2009; Feinberg et al., 2010), contactin (Boyle et al., 2001), or $\beta$ II-spectrin (Zhang et al., 2013), Kv1 channels relocate from the JXP to the adjacent paranodes. In addition to the JXP, Kv1 channels are also found in a double line flanking a single line of Caspr along the mesaxon and below the SLI, where they may attenuate current leakage through these sites (Arroyo et al., 1999). This unique membrane domain apposes the inner lip of the myelin sheath and contains the same glial CAMs that are present at the PNJ and the JXP (Poliak et al., 2002; Traka et al., 2003; Pedraza et al., 2009). However, in both $\mathrm{Caspr}^{-1-}$ and Caspr2 ${ }^{-1-}$, there is an increase in the amount of Kv1 channels at the mesaxonal line (Bhat et al., 2001; Poliak et al., 2003; Ivanovic et al., 2012). Conversely, when disrupting the axon-glia contact along the internode, the localization of Kvl channels along the mesaxonal line is disrupted 
A

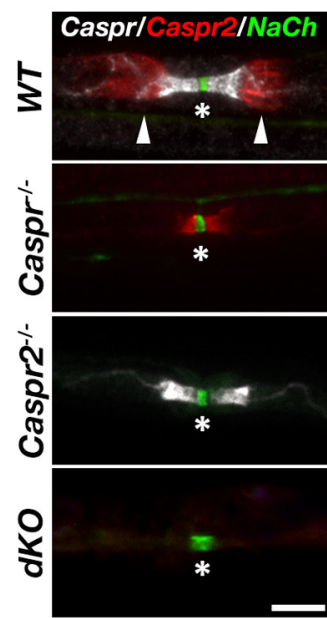

B

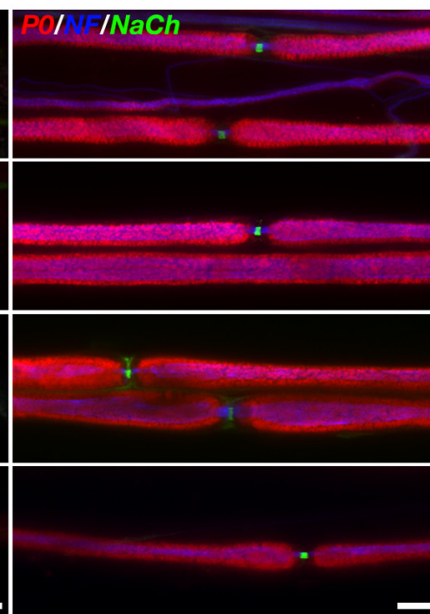

C

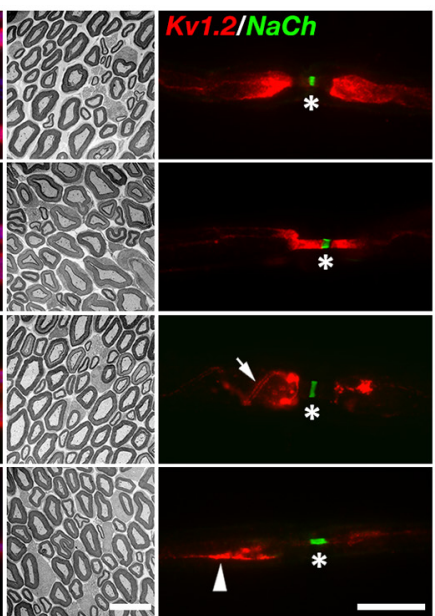

E

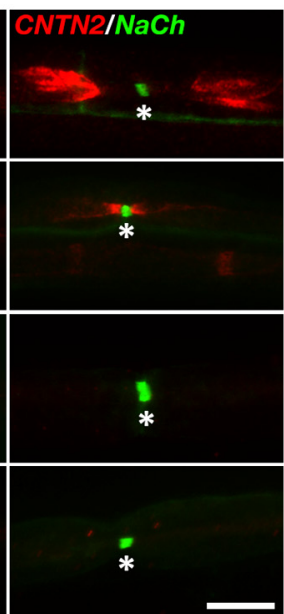

Figure 1. Caspr and Caspr2, respectively, dictate the location and membrane accumulation of Kv1 channels at the nodal environ. $\boldsymbol{A}$, Caspr and Caspr2 are not detectable in dK0 mice.

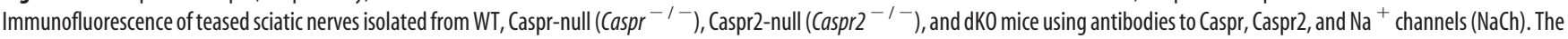
location of the nodes and the juxtaparanodal region are labeled with asterisks and arrowheads, respectively. Note that Caspr 2 is mislocalized at the paranodes in the absence of Caspr, whereas the distribution of Caspr is unchanged in the absence of Caspr2. B, C, Absence of both Caspr and Caspr2 does not lead to myelin abnormalities. Immunofluorescence analysis using antibodies to P0, neurofilament (NF) and $\mathrm{NaCh}(\boldsymbol{B})$, as well as electron microscopy analysis of cross-sections ( $\boldsymbol{C}$ of sciatic nerves isolated from the indicated genotypes. $\boldsymbol{D}, \boldsymbol{E}$, Absence of $C$ aspr or $\boldsymbol{C a s p r} 2$ results in altered distribution of juxtaparanodal components. Shown is immunofluorescence labeling of teased sciatic nerves isolated from the indicated genotypes using antibodies to NaCh and Kv1.2 potassium channels (D) or CNTN2 (E). The location of the nodes of Ranvier is marked with an asterisk in all panels. In the absence of Caspr2, Kv1.2 channels are not accumulated at the juxtaparanodal region, but are occasionally detected at the double mesaxonal lines that passed through this region (arrow). Arrowhead marks the presence of abnormal patches of Kv1 channels at the edge of the juxtaparanodal region in the dKO nerves. Scale bars: $\boldsymbol{A}, \boldsymbol{B}, \boldsymbol{D}, \boldsymbol{E}, 10 \mu \mathrm{m} ; \boldsymbol{C}, 5 \mu \mathrm{m}$.

(Ivanovic et al., 2012; Golan et al., 2013). This glial disruption of the mesaxon is likely mediated via axonal CAMs linking the inner Schwann cell membrane to the axon (i.e., Caspr-contactinneurofascin155 and Caspr2-Cntn2 complexes; Charles et al., 2002; Poliak et al., 2003; Traka et al., 2003). Because the single deletion of either Caspr or Caspr2 does not result in disruption of the mesaxon, we have generated mice lacking both Caspr genes to understand the axonal mechanism of Kvl channel clustering along the internodes. We report that Caspr and Caspr2 govern the clustering of voltage-gated channels at both the longitudinal aspect of the axolemma (nodal domains) and the radial (mesaxonal) domain.

\section{Materials and Methods}

Mice. Generation and genotyping of Caspr and Caspr2-null mice have been described previously (Gollan et al., 2003; Poliak et al., 2003). Either males or females were used. All experiments were performed in compliance with the relevant laws and institutional guidelines of the Weizmann Institute's Institutional Animal Care and Use Committee. Sciatic nerves conductivity measurements were performed as described previously (Feinberg et al., 2010).

Antibodies. Antibodies against Gliomedin (Eshed et al., 2005), 4.1B (Gollan et al., 2002), Caspr (Peles et al., 1997), Caspr2 (Poliak et al., 1999), and TAG1 (Horresh et al., 2010) were described previously. Antibodies to neurofascin (A4/3.4), Kv1.2, and $\beta$ IV-spectrin (Yang et al., 2004) were a gift from Dr. M. Rasband (Baylor College of Medicine). In addition, the following antibodies were used: mouse monoclonal antibodies to $\mathrm{Na}^{+}$channels (Sigma Aldrich), ankyrin G (Neuromab), $\beta$-dystroglycan (Novocastra), E-Cadherin (Transduction Laboratories), and myelin associated glycoprotein (MAG; Roche); rabbit antibodies to pERM (Cell Signaling Technology), syndecan3 (Abcam), NrCAM (Abcam); rat anti-neurofilament $\mathrm{H}$ (Millipore); chicken antibody to P0 (Aves); 488-, Cy3-, and Cy5-coupled antibodies were obtained from Jackson ImmunoResearch.

Immunofluorescence labeling and Western blot analysis. Sciatic nerves were prepared as described previously (Golan et al., 2013). Samples were postfixed for $7 \mathrm{~min}$ using cold methanol $\left(-20^{\circ} \mathrm{C}\right)$ and then washed with
PBS. Blocking and permeabilization were done by incubation for 45-60 min in 5\% normal goat serum and $0.5 \%$ Triton X-100 in PBS at room temperature. Primary antibodies were diluted in 5\% normal goat serum and $0.2 \%$ Triton X-100 in PBS and incubated overnight at $4^{\circ} \mathrm{C}$. Secondary antibodies were incubated for $45 \mathrm{~min}$ at room temperature in 5\% normal goat serum and $0.1 \%$ Triton X-100 in PBS. Samples were mounted with elvanol. All quantitations were performed on teased sciatic nerves. Samples from at least three animals were used per genotype. Statistical significance was determined using Student's two-tailed $t$ test. Images were taken using a Nikon Eclipse 90i microscope or a Zeiss LSM710 confocal microscope. Western blot analyses of sciatic nerves were done as described previously (Horresh et al., 2010). Imaging was performed using ChemiDoc MP (Bio-Rad) using Image Lab software (Bio-Rad).

Electron microscopy. For electron microscopy, animals were killed and sciatic nerves exposed and fixed by dripping of $4 \%$ paraformaldehyde, $2.5 \%$ glutaraldehyde, and $0.1 \mathrm{~m}$ sodium cacodylate, $\mathrm{pH} 7.4$, in PBS for 40 $\mathrm{min}$. Sciatic nerves were then removed and rotated overnight in fixative at room temperature. Samples were then transferred to $4^{\circ} \mathrm{C}$ until processing. Processing was performed as described previously (Novak et al., 2011). Sections were imaged using a Philips CM-12 transmission electron microscope.

\section{Results}

Caspr 2 is required for paranodal clustering of Kv1 channels in the absence of Caspr

Heterozygous mice lacking Caspr (Gollan et al., 2003; Feinberg et al., 2010; Rosenbluth et al., 2012) and Caspr2 (Poliak et al., 2003) were crossed to obtain mice lacking both Caspr genes. Immunofluorescence labeling of teased sciatic nerves isolated from wildtype (WT), caspr ${ }^{-1-}$, caspr2 $^{-1-}$, and Caspr ${ }^{-1-}$ Caspr2 $2^{-1-}$ (referred to herein as $\mathrm{dKO}$ ) using antibodies to $\mathrm{Na}^{+}$channels, Caspr and Caspr2, confirmed the genotype of the mice mutants used in this study (Fig. 1A). Although Caspr2 was present at JXP in WT nerves, it was found at the paranodes flanking the nodes of Ranvier in Caspr ${ }^{-1-}$, and was undetectable in Caspr2 ${ }^{-1-}$ and $\mathrm{dKO}$ nerves. Caspr was localized to the PNJ in both WT and 
caspr $2^{-1-}$ nerves and, as expected, was undetectable in nerves isolated from caspr $^{-1-}$ and dKO mice. Phenotypically, $\mathrm{dKO}$ mice exhibit similar neurological impairments as Caspr ${ }^{-1-}$ mice, including motor weakness and ataxic tremor (Bhat et al., 2001; Gollan et al., 2003; Feinberg et al., 2010; Rosenbluth et al., 2012). They were smaller in size and showed even lower general locomotor activity than Caspr-null mice as judged by an open field test (data not shown). Analysis of compound action potential using isolated sciatic nerves revealed that $\mathrm{dKO}$ mice exhibit reduced nerve conduction velocity at $37^{\circ} \mathrm{C}(23.6 \pm 2.5 \mathrm{~ms} ; n=7$ vs WT $37.6 \pm$ $2.7 \mathrm{~ms} ; n=4$ ) that was not significantly different from the single Caspr $^{-1-}$ mutant $(26.5 \pm 6.8 \mathrm{~ms} ; n=5)$. Immunolabeling of teased sciatic nerves using an antibody against the compact myelin protein P0 (Fig. 1B), as well as electron microscopy analysis of cross-sectioned nerves (Fig. 1C), revealed the formation of normal myelin in all genotypes, indicating that the severe motor phenotype of $\mathrm{dKO}$ mice was not a result of myelin abnormalities.

In WT nerves, Kv1 channels are sequestered at the JXP, which is separated from the nodes by the PNJ (Wang et al., 1993). In agreement with previous studies (Bhat et al., 2001; Poliak et al., 2003; Horresh et al., 2010), we found that in the absence of Caspr, Kv1 channels were present at the paranodes flanking the nodes, whereas in the absence of Caspr2, they dispersed from the JXP toward the internodes (Fig. 1D). In Caspr2 ${ }^{-1-}$ nerves, Kv1 channels were present at the double mesaxonal lines that also passed through the JXP (Fig. 1D, arrow). In the dKO nerves, Kv1 channels did not accumulate at the paranodes or at the JXP and instead formed large aggregates that were randomly distributed along the internodes (Figs. 1D, 2). Other JXP components such as Cntn2, which associate with Caspr2 (Poliak et al., 2003; Traka et al., 2003), were present at the paranodes in Caspr ${ }^{-1-}$ mice, but were undetectable at the nodal environ in either Caspr $2^{-1-}$ or dKO mice (Fig. $1 E)$. These results indicate that Caspr and Caspr2 have complementary roles in localizing Kv1 channels around the nodes. Through its action at the PNJ, Caspr demarcates the juxtaparanodal area, whereas Caspr2 is required for the accumulation of Kv1 channels at the axonal membrane whether they are present at the JXP (i.e., in WT) or at the paranodes (i.e., in Caspr $^{-1-}$ mice).

\section{Simultaneous deletion of Caspr and Caspr2 disrupts the internodal organization of Kv1.2}

Freeze-fracture replica studies revealed that the membrane along the internodes contains two linear rows of juxtaparanodal-type intramembranous particles that flank a paranodal-type aggregate at the inner mesaxon and under the Schmidt-Lanterman incisures (Miller and Pinto da Silva, 1977; Stolinski et al., 1985). Similar to the JXP, the intramembranous particles found along the internodal mesaxonal line and the innermost aspect of the incisures (sometimes referred to as the juxta-mesaxonal and juxtaincisural lines, respectively) correspond to delayed rectifier $\mathrm{K}^{+}$ channels (Arroyo et al., 1999). In accordance with the freezefracture data, this axolemmal membrane domain consists of a single line of Caspr flanked on both sides by a line of Caspr2 and Kv1.2 (Arroyo et al., 1999). Immunolabeling of teased sciatic nerves using antibodies to Kv1.2 demonstrated that both $\mathrm{Caspr}^{-1-}$ and Caspr2 ${ }^{-1-}$ mice had higher intensity of Kv1 channels at the internodal mesaxonal line than WT nerves (Fig. $2 A)$. In the $\mathrm{dKO}$ nerves, Kv1.2 channels frequently formed large $(0.2-0.4 \mu \mathrm{m})$ aggregates that were distributed along the internode (Fig. 2A). These aggregates were only detected in the PNS (data not shown). Triple immunofluorescence labeling of crosssections of sciatic nerves using antibodies to dystroglycan (labeling the abaxonal membrane) neurofilament (labeling the axon), and Kv1.2 demonstrated that these aggregates were found in proximity to the axolemma (Fig. $2 B$ ). Western blot analysis of sciatic nerve lysates revealed that the total amount of Kv1.2 in the $\mathrm{dKO}$ was comparable to that of the other genotypes (Fig. 2C), indicating that the abnormal aggregation of these channels was 

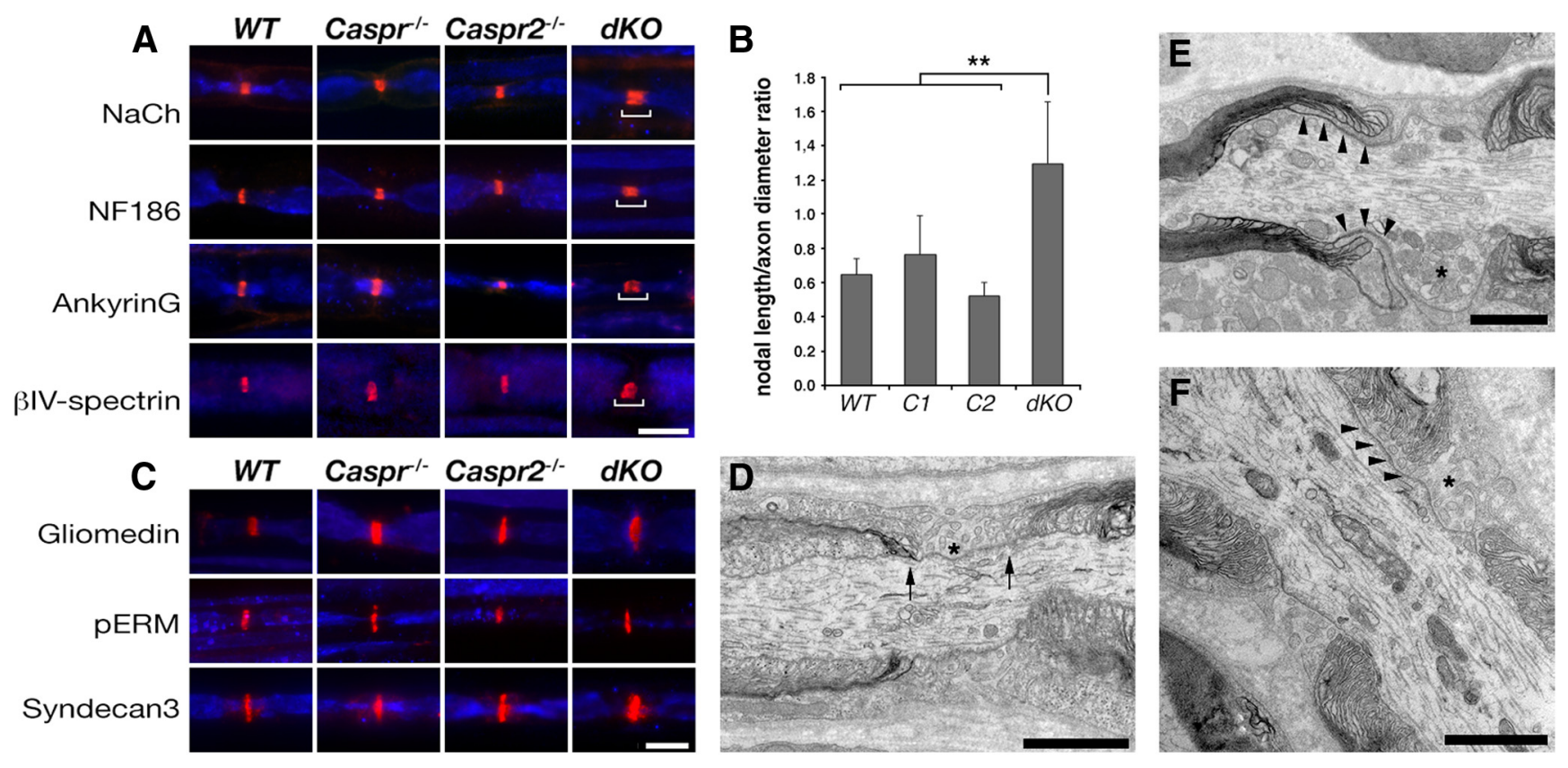

Figure 3. Deletion of both Caspr and Caspr 2 results in widening of the nodes. $A$, Double immunofluorescence labeling of sciatic nerves isolated from the indicated genotypes using antibodies to neurofilament (blue) and axonodal components: $\mathrm{Na}^{+}$channels (NaCh), NF186, ankyrin G, or $\beta \mathrm{IV}$ spectrin. Bars highlight the wider nodal region in the dKO nerves. $\boldsymbol{B}$, Quantification of axonodal width-to-height ratio showed a widening of the dKO node compared with WT mice and the single mutants. Error bars indicate SEM of $n=4$ mice for each genotype $\left.{ }^{* *} p<0.05\right)$. C, Double immunofluorescence labeling of sciatic nerves isolated from the indicated genotypes using antibodies to neurofilament (blue) and glial microvilli proteins: gliomedin, phospho-ERM (pERM), or Syndecan-3. $\boldsymbol{D}-\boldsymbol{F}$, Electron microscopy images showing a longitudinal view of the nodes of Ranvier in sciatic nerves of WT $(\boldsymbol{D})$ and dKO $(\boldsymbol{E}, \boldsymbol{F})$ mice. In WT nerves, the node is bordered by the PNJ and Schwann cell microvilli (asterisk) are confined to the nodal gap (arrows). In dKO nerves, Schwann cell microvilli processes are detected between the axolemma and the detached paranodal loops ( $\boldsymbol{E}, \boldsymbol{F}$, arrowheads). Asterisks in $\boldsymbol{E}$ and $\boldsymbol{F}$ mark microvilli and the accumulation of mitochondria at the nodes, respectively. Scale bars: $\boldsymbol{A}, \boldsymbol{C}, 10 \mu \mathrm{m} ; \boldsymbol{D}-\boldsymbol{F}, 1 \mu \mathrm{m}$.

not due to an increase in their expression. Kv1 channels aggregates were not found in association with other internodal axonal markers such as the cytoskeletal linker protein $4.1 \mathrm{~B}$ and the cell adhesion molecule Cadm3/Necl1 (Fig. 2D and data not shown). In addition, NF155, which is present at the Schwann cell adaxonal membrane opposing Caspr in WT nerves (Ivanovic et al., 2012), was detected neither along the mesaxonal line nor adjacent to Kv1 channel clusters in the dKO (data not shown). Labeling of teased sciatic nerves using antibodies to the noncompact myelin proteins E-cadherin and MAG showed the normal morphology of Schmidt-Lanterman incisures in all four genotypes (Fig. 2E$F$ ). Interestingly, we noted that typically only one of these large aggregates was present between two neighboring SchmidtLanterman incisures. Altogether, these results suggest that in the absence of both Caspr and Caspr2, Kv1 channels are correctly expressed and targeted to the axonal membrane but are not able to cluster at axoglial contact sites (i.e., JXP and the internodal mesaxonal line). They further demonstrate that, unlike the JXP, where Caspr2 is necessary for Kv1 clustering, at the internodal mesaxonal line, either Caspr or Caspr2 are sufficient to cluster these channels.

\section{Absence of both Caspr and Caspr 2 results in the widening of the nodes of Ranvier}

To further examine the role of Caspr proteins in the organization of myelinated axons, we labeled teased sciatic nerves from all genotypes using antibodies to different axonodal components. In agreement with previous studies done using a mutant mouse lacking Caspr and the cytokine receptor CCR10 (Ccr10/Cntnap1 ${ }^{\text {tm1Bhat; }}$ Bhat et al., 2001; Rios et al., 2003), nodes in Caspr ${ }^{-1-}$ mice were slightly longer than those of WT littermates (Fig. $3 A, B$ ). As expected, the nodal length was comparable between Caspr $2^{-1-}$ and WT mice (Fig. 3A,B; Poliak et al., 2003). In contrast, in $\mathrm{dKO}$ nerves, nodal $\mathrm{Na}^{+}$ channel immunoreactivity was wider than all other genotypes (Fig. $3 A$ ). Nodal length-to-width ratios were 2 -fold higher in the dKO than in WT and Caspr $2^{-1-}(1.12 \pm 0.14,0.68 \pm 0.11$, and $0.69 \pm 0.14$, respectively) and 1.6-fold higher than Caspr $^{-1-}(0.68 \pm 0.11)$ nodes (Fig. 3B). Expansion of the nodal domain was also detected using antibodies to both axonal membrane components ( $\mathrm{NaCh}$ and NF186) and intracellular axonal proteins ( $\beta \mathrm{IV}$-spectrin and ankyrin $\mathrm{G}$ ) (Fig. $3 A$ ). However, immunolabeling of teased sciatic nerves using antibodies to Schwann cell microvilli (i.e., gliomedin, phospho-ERM, and syndecan-3) showed that, in contrast to the widening of the area occupied by axonodal proteins, the glial aspect of nodes of Ranvier is not enlarged in $\mathrm{dKO}$ nerves. Electron microscopy analysis of longitudinal sections of sciatic nerves isolated from $\mathrm{dKO}$ mice revealed that, in this mutant, the paranodal loops were detached from the axonal membrane and no septate-like junctions were observed; the nodal gap (defined as the distance between paranodal loops that flank the nodes) was not extended and was filled with Schwann cell microvilli that contacted the nodal axolemma similar to WT nerves (Fig. 3D-F). However, in contrast to the latter, in $\mathrm{dKO}$ mice these Schwann cell microvilli often intercalate between the detached paranodal loops and the axolemma, thereby extending the nodal domain (Fig. $3 E, F$ ). In addition, we observed the accumulation of enlarged mitochondria at the node of dKO mice similar to those found in the absence of Caspr (Einheber et al., 2006). The expansion of the nodal axolemma detected in $\mathrm{dKO}$ mice demonstrates that, in the PNS, Caspr and Caspr2 provide overlapping functions in 

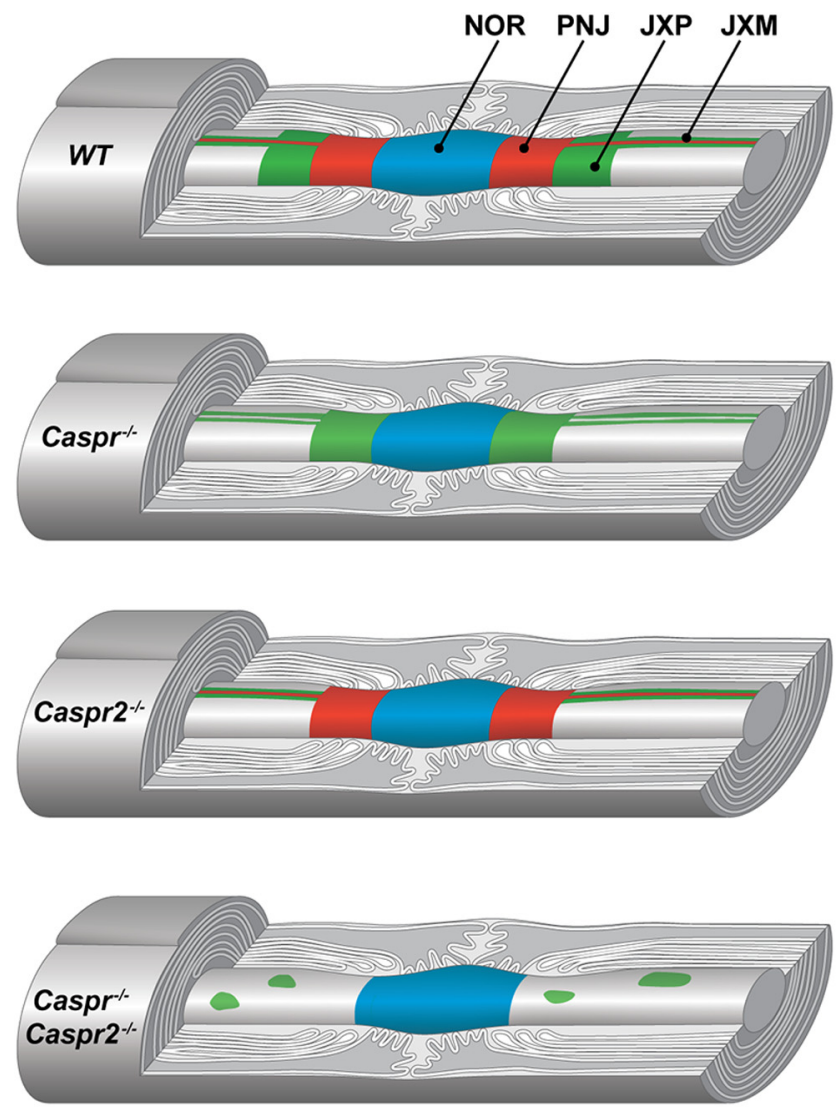

NaCh Caspr Kv1.2

Figure 4. Caspr proteins organize myelinated axons. A schematic drawing illustrating the distribution of $\mathrm{Na}^{+}$channels (NaCh), Caspr, and Kv1.2 channels along myelinated PNS axons in WT, Caspr ${ }^{-1-}$, Caspr2 $2^{-1-}$, and double Caspr ${ }^{-1-} /$ Caspr2 $^{-1-}$ mutant mice. Whereas in Caspr $^{-1-}$ or Caspr ${ }^{-1-}$ nerves, Kv1.2 channels accumulate at the JXM, in the absence of both Caspr proteins, these channels form large aggregates along the internodal axolemma. NOR indicates node of Ranvier; PNJ, paranodal junction; and JXP, juxtaparanodal region.

sequestering the voltage-gated sodium channels at the node of Ranvier.

\section{Discussion}

The precise localization of ion channels to membrane domains is critical for action potential propagation along myelinated axons. This membrane organization is controlled by myelinating glial cells through the action of axoglial CAMs and cytoskeletal proteins (Eshed-Eisenbach and Peles, 2013). In peripheral myelinated axons, Kv1 channels concentrate at the JXP and at distinct sites along the internodes (Wang et al., 1993; Arroyo et al., 1999; Fig. 4, WT). Along the internodal domain, the membrane contains two parallel rows of juxtaparanodal-type intramembranous particles that flank a paranodal-type aggregate at the inner mesaxon and under the Schmidt-Lanterman incisures (Miller and Pinto da Silva, 1977; Stolinski et al., 1985). However, in contrast to the PNJ, no distinct junctional specialization (e.g., transverse bands) is present between the axolemma and the adaxonal Schwann cell membrane at the inner mesaxon. Similar to the JXP, the aggregates found at the mesaxonal lines correspond to delayed rectifier $\mathrm{K}^{+}$channels (Arroyo et al., 1999). Therefore, the radial organization of paranodal and juxtaparanodal components along the internodes corresponds to the longitudinal polarity of these proteins near the nodes of Ranvier.
Here, we show that whereas the clustering of Kv1 channels at the JXP (i.e., longitudinal organization) depends on both Caspr and Caspr2, the accumulation of these channels along the mesaxonal lines (i.e., radial membrane organization) requires either one of these proteins. On the longitudinal aspect, juxtaparanodal clustering of Kv1 channels depends on both the formation of a Caspr-dependent membrane barrier at the PNJ and the generation of a juxtaparanodal adhesion scaffolding complex by Caspr2 (Poliak and Peles, 2003; Eshed-Eisenbach and Peles, 2013). In peripheral nerves of mutants lacking Caspr, Kv1 channels relocate from the JXP to the paranodal region, but they are still present at the internodal mesaxonal lines (Fig. 4, $\mathrm{Caspr}^{-1-}$ ). Likewise, whereas Kv1 channels do not cluster at the JXP in mice mutants lacking Caspr2, they concentrate at the mesaxonal lines along the internodes (Fig. 4, Caspr2 $2^{-1-}$ ). In contrast, in the absence of both Caspr proteins, Kv1 channels form large aggregates along the internodal axolemma (Fig. 4, Caspr ${ }^{-1-} / \mathrm{Caspr}^{-1-}$ ), showing that the internodal mesaxonal clustering of these channels depends on the presence of either Caspr or Caspr2. Therefore, in contrast to longitudinal axonal polarity, on the radial aspect, Kv1 channel clustering requires either Caspr or Caspr2. Our results support the existence of membrane barriers at both the PNJ and the mesaxonal line that regulate the clustering of $\mathrm{Kv} 1$ channels in peripheral myelinated axons. While the PNJ barrier controls the longitudinal distribution of Kv1 channels, the presence of this membrane barrier at the juxtamesaxonal line only affects the distribution of these channels around the axon circumference (radial). In the absence of the PNJ barrier in Casprdeficient nerves, Kv1 channels are still trapped at the mesaxonal line by Caspr2, whereas in Caspr2-deficient axons, these channels are located at the mesaxonal lines due to the presence of the Caspr-mediated membrane barrier. In contrast, in $\mathrm{dKO}$ mice, both the Caspr-dependent membrane barrier and the Caspr2dependent membrane scaffold are missing, resulting in the diffusion of Kvl channels away from the mesaxonal line and their abnormal aggregation. One possibility for the aberrant aggregation of Kvl channels is that it involves scaffolding proteins such as PSD93. This idea is supported by previous studies showing that PSD-93 mediates Caspr2-independent clustering of Kv1 channels at the axonal initial segment (Ogawa et al., 2008). Because the Caspr-dependent PNJ barrier is mediated through the axonal $\beta \mathrm{II}$ Spectrin effector protein (Zhang et al., 2013), it would be of interest to examine the role spectrin-based submembranous cytoskeleton plays in the internodal organization using mice lacking both $\beta$ II Spectrin and Caspr2.

The molecular assembly and maintenance of the nodes of Ranvier in the PNS is controlled by two complementary mechanisms: clustering of axonodal NF186 and $\mathrm{Na}^{+}$channels by gliomedin present on the Schwann cell microvilli and restricting the distribution of $\mathrm{Na}^{+}$channels to the forming nodal gap by a Caspr-dependent diffusion barrier present at the PNJ (Feinberg et al., 2010). The latter is also the main mechanism operating in the CNS (Susuki et al., 2013). Although each mechanism is sufficient for node formation in the PNS, both are required for the long-term maintenance of this domain (Rios et al., 2003; Amor et al., 2014). In the absence of the PNJ in Caspr KO mice, sodium channels are still clustered but the nodal axolemma is slightly elongated (Rios et al., 2003). We found that, in the absence of both Caspr and Caspr2, this enlargement of the nodes is more severe, resulting in a nodal axolemma that is approximately twice as long as that of WT nodes. Given that the distribution of microvilli proteins in $\mathrm{dKO}$ appeared normal, we concluded that the nodal widening reflects an expansion of the nodal axolemma 
rather than an overall increase of the nodal gap (defined by the distance between paranodal loops flanking a node on either side). This conclusion was further supported by electron microscopy data revealing the intercalation of Schwann cell microvilli between the detached paranodal loops and the axon. In addition to the loss of the paranodal barrier (allowing the lateral diffusion of nodal channels), such an insertion of Schwann cell microvilli may result in the presentation of gliomedin to the axon and further recruitment of NF186 and $\mathrm{Na}^{+}$channels (Eshed et al., 2005). We also noted that $\mathrm{Na}^{+}$channel immunoreactivity partially overlapped with E-cadherin-labeled paranodal loops in the $\mathrm{dKO}$, but not in WT nerves (data not shown), further indicating the expansion of the nodal axolemma. Because Caspr2 is found flanking the nodes in Caspr-null mice, this result indicates that Caspr2 can also contribute to the formation of a diffusion barrier in the axolemma sequestering the voltage-gated sodium channels to the node. Such a compensatory role for Caspr2 is supported by previous studies in older mice lacking Caspr, which found a correlation between the presence of Kv1 (and thus Caspr2) at the paranodes and nodal preservation (Rios et al., 2003). Although yet to be determined, it is likely that this function of Caspr2 may be mediated by its ability to interact with similar cytoskeletal proteins as Caspr (Horresh et al., 2010).

The absence of both Caspr and Caspr2 results in a marked increase in the length of the nodal axolemma. Therefore, in $\mathrm{dKO}$ mice, two key morphological determinants of nerve conduction velocity $(\mathrm{NCV})$, the nodal length and the PNJ, are disrupted. Nevertheless, NCV in these animals was not significantly different from that of the single Caspr ${ }^{-1-}$ mutant, which reflects the larger effect that the decrease in paranodal resistance has on NCV (Babbs and Shi, 2013). Furthermore, given that Kv1 channels are absent from the paranodal area in the $\mathrm{dKO}$ mutant, our results suggest that the presence of these channels near the nodes in paranodal mutant mice such as Caspr ${ }^{-1-}$ (Feinberg et al., 2010),

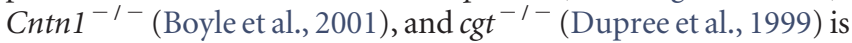
not the primary cause of the reduced NCV observed. In agreement, blocking the function of these channels after disruption of the PNJ results in an increase in the amplitude and refractory period, but not in NCV (Boyle et al., 2001). This is of particular interest because the movement of juxtaparanodal Kv1 channels toward the nodes of Ranvier in cases in which the PNJ are compromised was suggested to contribute to the loss of action potential propagation in demyelinating pathologies (ArancibiaCarcamo and Attwell, 2014).

\section{References}

Amor V, Feinberg K, Eshed-Eisenbach Y, Vainshtein A, Frechter S, Grumet M, Rosenbluth J, Peles E (2014) Long-term maintenance of $\mathrm{Na}+$ channels at nodes of Ranvier depends on glial contact mediated by gliomedin and NrCAM. J Neurosci 34:5089-5098. CrossRef Medline

Arancibia-Carcamo IL, Attwell D (2014) The node of Ranvier in CNS pathology. Acta Neuropathol 128:161-175. CrossRef Medline

Arroyo EJ, Xu YT, Zhou L, Messing A, Peles E, Chiu SY, Scherer SS (1999) Myelinating Schwann cells determine the internodal localization of Kv1.1, Kv1.2, Kvbeta2, and Caspr. J Neurocytol 28:333-347. CrossRef Medline

Babbs CF, Shi R (2013) Subtle paranodal injury slows impulse conduction in a mathematical model of myelinated axons. PLoS One 8:e67767. CrossRef Medline

Bhat MA, Rios JC, Lu Y, Garcia-Fresco GP, Ching W, St Martin M, Li J, Einheber S, Chesler M, Rosenbluth J, Salzer JL, Bellen HJ (2001) Axonglia interactions and the domain organization of myelinated axons requires neurexin IV/Caspr/Paranodin. Neuron 30:369-383. CrossRef Medline

Boyle ME, Berglund EO, Murai KK, Weber L, Peles E, Ranscht B (2001) Contactin orchestrates assembly of the septate-like junctions at the para- node in myelinated peripheral nerve. Neuron 30:385-397. CrossRef Medline

Charles P, Tait S, Faivre-Sarrailh C, Barbin G, Gunn-Moore F, DenisenkoNehrbass N, Guennoc AM, Girault JA, Brophy PJ, Lubetzki C (2002) Neurofascin is a glial receptor for the paranodin/Caspr-contactin axonal complex at the axoglial junction. Curr Biol 12:217-220. CrossRef Medline

Dupree JL, Girault JA, Popko B (1999) Axo-glial interactions regulate the localization of axonal paranodal proteins. J Cell Biol 147:1145-1152. CrossRef Medline

Einheber S, Bhat MA, Salzer JL (2006) Disrupted axo-glial junctions result in accumulation of abnormal mitochondria at nodes of ranvier. Neuron Glia Biol 2:165-174. CrossRef Medline

Eshed Y, Feinberg K, Poliak S, Sabanay H, Sarig-Nadir O, Spiegel I, Bermingham JR Jr, Peles E (2005) Gliomedin mediates Schwann cell-axon interaction and the molecular assembly of the nodes of Ranvier. Neuron 47: 215-229. CrossRef Medline

Eshed-Eisenbach Y, Peles E (2013) The making of a node: a co-production of neurons and glia. Curr Opin Neurobiol 23:1049-1056. CrossRef Medline

Feinberg K, Eshed-Eisenbach Y, Frechter S, Amor V, Salomon D, Sabanay H, Dupree JL, Grumet M, Brophy PJ, Shrager P, Peles E (2010) A glial signal consisting of gliomedin and NrCAM clusters axonal $\mathrm{Na}+$ channels during the formation of nodes of Ranvier. Neuron 65:490-502. CrossRef Medline

Golan N, Kartvelishvily E, Spiegel I, Salomon D, Sabanay H, Rechav K, Vainshtein A, Frechter S, Maik-Rachline G, Eshed-Eisenbach Y, Momoi T, Peles E (2013) Genetic deletion of Cadm4 results in myelin abnormalities resembling Charcot-Marie-Tooth neuropathy. J Neurosci 33:10950 10961. CrossRef Medline

Gollan L, Sabanay H, Poliak S, Berglund EO, Ranscht B, Peles E (2002) Retention of a cell adhesion complex at the paranodal junction requires the cytoplasmic region of Caspr. J Cell Biol 157:1247-1256. CrossRef Medline

Gollan L, Salomon D, Salzer JL, Peles E (2003) Caspr regulates the processing of contactin and inhibits its binding to neurofascin. J Cell Biol 163: 1213-1218. CrossRef Medline

Horresh I, Bar V, Kissil JL, Peles E (2010) Organization of myelinated axons by Caspr and Caspr2 requires the cytoskeletal adapter protein 4.1B. J Neurosci 30:2480-2489. CrossRef Medline

Ivanovic A, Horresh I, Golan N, Spiegel I, Sabanay H, Frechter S, Ohno S, Terada N, Möbius W, Rosenbluth J, Brose N, Peles E (2012) The cytoskeletal adapter protein $4.1 \mathrm{G}$ organizes the internodes in peripheral myelinated nerves. J Cell Biol 196:337-344. CrossRef Medline

Miller RG, Pinto da Silva P (1977) Particle rosettes in the periaxonal Schwann cell membrane and particle clusters in the axolemma of rat sciatic nerve. Brain Res 130:135-141. CrossRef Medline

Novak N, Bar V, Sabanay H, Frechter S, Jaegle M, Snapper SB, Meijer D, Peles E (2011) N-WASP is required for membrane wrapping and myelination by Schwann cells. J Cell Biol 192:243-250. CrossRef Medline

Ogawa Y, Horresh I, Trimmer JS, Bredt DS, Peles E, Rasband MN (2008) Postsynaptic density-93 clusters Kv1 channels at axon initial segments independently of Caspr2. J Neurosci 28:5731-5739. CrossRef Medline

Pedraza L, Huang JK, Colman D (2009) Disposition of axonal caspr with respect to glial cell membranes: Implications for the process of myelination. J Neurosci Res 87:3480-3491. CrossRef Medline

Peles E, Nativ M, Lustig M, Grumet M, Schilling J, Martinez R, Plowman GD, Schlessinger J (1997) Identification of a novel contactin-associated transmembrane receptor with multiple domains implicated in proteinprotein interactions. EMBO J 16:978-988. CrossRef Medline

Poliak S, Peles E (2003) The local differentiation of myelinated axons at nodes of Ranvier. Nat Rev Neurosci 4:968-980. CrossRef Medline

Poliak S, Gollan L, Martinez R, Custer A, Einheber S, Salzer JL, Trimmer JS, Shrager P, Peles E (1999) Caspr2, a new member of the neurexin superfamily, is localized at the juxtaparanodes of myelinated axons and associates with K+ channels. Neuron 24:1037-1047. CrossRef Medline

Poliak S, Matlis S, Ullmer C, Scherer SS, Peles E (2002) Distinct claudins and associated PDZ proteins form different autotypic tight junctions in myelinating Schwann cells. J Cell Biol 159:361-372. CrossRef Medline

Poliak S, Salomon D, Elhanany H, Sabanay H, Kiernan B, Pevny L, Stewart CL, Xu X, Chiu SY, Shrager P, Furley AJ, Peles E (2003) Juxtaparanodal clustering of Shaker-like $\mathrm{K}+$ channels in myelinated axons depends on Caspr2 and TAG-1. J Cell Biol 162:1149-1160. CrossRef Medline 
Rios JC, Rubin M, St Martin M, Downey RT, Einheber S, Rosenbluth J, Levinson SR, Bhat M, Salzer JL (2003) Paranodal interactions regulate expression of sodium channel subtypes and provide a diffusion barrier for the node of Ranvier. J Neurosci 23:7001-7011. Medline

Rosenbluth J, Petzold C, Peles E (2012) Dependence of paranodal junctional gap width on transverse bands. J Comp Neurol 520:2774-2784. CrossRef Medline

Stolinski C, Breathnach AS, Thomas PK, Gabriel G, King RH (1985) Distribution of particle aggregates in the internodal axolemma and adaxonal Schwann cell membrane of rodent peripheral nerve. J Neurol Sci 67:213222. CrossRef Medline

Sun XY, Takagishi Y, Okabe E, Chishima Y, Kanou Y, Murase S, Mizumura K, Inaba M, Komatsu Y, Hayashi Y, Peles E, Oda S, Murata Y (2009) A novel Caspr mutation causes the shambling mouse phenotype by disrupting axoglial interactions of myelinated nerves. J Neuropathol Exp Neurol 68:1207-1218. CrossRef Medline

Susuki K, Chang KJ, Zollinger DR, Liu Y, Ogawa Y, Eshed-Eisenbach Y, Dours-Zimmermann MT, Oses-Prieto JA, Burlingame AL, Seidenbecher
CI, Zimmermann DR, Oohashi T, Peles E, Rasband MN (2013) Three mechanisms assemble central nervous system nodes of Ranvier. Neuron 78:469-482. CrossRef Medline

Traka M, Goutebroze L, Denisenko N, Bessa M, Nifli A, Havaki S, Iwakura Y, Fukamauchi F, Watanabe K, Soliven B, Girault JA, Karagogeos D (2003) Association of TAG-1 with Caspr2 is essential for the molecular organization of juxtaparanodal regions of myelinated fibers. J Cell Biol 162: 1161-1172. CrossRef Medline

Wang H, Kunkel DD, Martin TM, Schwartzkroin PA, Tempel BL (1993) Heteromultimeric $\mathrm{K}+$ channels in terminal and juxtaparanodal regions of neurons. Nature 365:75-79. CrossRef Medline

Yang Y, Lacas-Gervais S, Morest DK, Solimena M, Rasband MN (2004) BetaIV spectrins are essential for membrane stability and the molecular organization of nodes of Ranvier. J Neurosci 24:7230-7240. CrossRef Medline

Zhang C, Susuki K, Zollinger DR, Dupree JL, Rasband MN (2013) Membrane domain organization of myelinated axons requires betaII spectrin. J Cell Biol 203:437-443. CrossRef Medline 